\title{
The Smithsonian Institution Libraries: Afoot in Three Camps
}

\author{
Nancy E. Gwinn
}

The origin of the Smithsonian Institution Libraries (SIL) is rooted in the founding charter of the institution, but collection development has been substantially affected by the libraries' position within a museum context. SIL operates within three "camps," or environments, simultaneously-museums, research libraries, and special libraries-and utilizes policies and practices that contain elements of each. SIL has internally adopted the nomenclature that applies to management of museum object collections and capitalized on allied interests in such areas as preservation. Ironically, SIL must often assert and defend its role as a "collector" to ensure inclusion in Smithsonian funding programs.

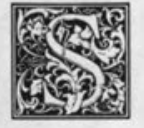

ince I joined the Smithsonian four years ago, I don't know how many times I have heard "I didn't know the Smithsonian had a library!" Nevertheless, I have come to understand this invisibility and also to regard the Smithsonian Institution Libraries as one of Washington's bestkept secrets. This article lifts the veil and provides a glimpse of what library life is like behind the scenes at the Smithsonian, within the framework of collection development and preservation activities.

I have been asked to answer certain questions in this article, such as: (1) What are the demands of the curatorial staff? (2) How do we meet them? (3) Do the purposes of the Smithsonian museums conflict with our duties as librarians? (4) Have either the museums or the libraries changed policies or procedures in light of these differences or because we've learned from one another? I am inclined to answer somewhat facetiously: (1) instant access, immediate delivery, indefinite loan; (2) with difficulty and ease; (3) purposes-no; cross-purposes-yes; (4) yes and no-and go home. However, if I have learned one lesson, it is never to make a generalization about how we, or anyone else in the Smithsonian, operate. But this heterogeneity is also what makes talking about the Smithsonian fascinating and worthy of attention.

\section{SMITHSONIAN ORIGINS}

To understand the answers to these questions, we must place them within the context of a brief historical overview of the development of the Institution and its library collections. James Smithson, illegitimate son of the Duke of Northumberland, was born in 1765 . Educated at Pembroke, he became a natural scientist and fellow of the Royal Society. His twenty-seven published papers are reported to contain "a wide range of research, from the origin of the earth, the nature of the colors of the

Nancy E. Gwinn is Assistant Director, Collections Management, at the Smithsonian Institution Libraries, Washington, D.C. 20560. This article was adapted from a presentation given at the ACRL Rare Books and Manuscripts Preconference, "Libraries and Museums: Leaves from Each Others' Books," July 6, 1988, in New Orleans, Louisiana. 
vegetables and insects, the analysis of minerals and chemicals, to an improved method of constructing lamps or of making coffee. ${ }^{\prime 1}$ In 1829 Smithson died, leaving his estate to his nephew, then unmarried, and to any of the nephew's children, legitimate or otherwise. But his will, in a truly remarkable bequest, stipulated that should the nephew die without leaving heirs, the whole of the property was to go "to the United States of America, to found at Washington, under the name of the Smithsonian Institution, an establishment for the increase and diffusion of knowledge among men."'2 Nobody knows why Smithson, who never visited America, did this, but in a true fairy-tale ending, the nephew died heirless, and a half-million dollars came to the United States.

Congressional wrangling over acceptance of the bequest followed, but in due course Congress passed an act in 1846 that established the Institution and its Board of Regents; outlined the duties of the Secretary; transferred to it all federally owned objects of art, natural history, etc.; established and authorized funds for "the gradual formation of a library"; and directed that both this library and the Library of Congress receive one copy of all copyrighted publications. Joseph Henry was selected as Secretary, and he hired two extremely competent leaders as his assistants: Charles Coffin Jewett to establish the library and Spencer Fullerton Baird to, among other things, organize a museum and art gallery.

The Library of Congress was at this time a struggling, inadequately housed collection located in the U.S. Capitol building. It is easy to see that the groundwork was laid here for the Smithsonian to become eventually the nation's leading library. But this was not to be. The eternal triangle seemed to be at work in the personalities of these three eminent Type-A Victorian achievers. Firmly believing that Congress had misunderstood or ignored the intent of Smithson's bequest, Henry was committed to promoting original research and publication of results over any other objective. At least one slightly revisionist and definitely controversial study suggests that at first Jewett and Baird formed an al-

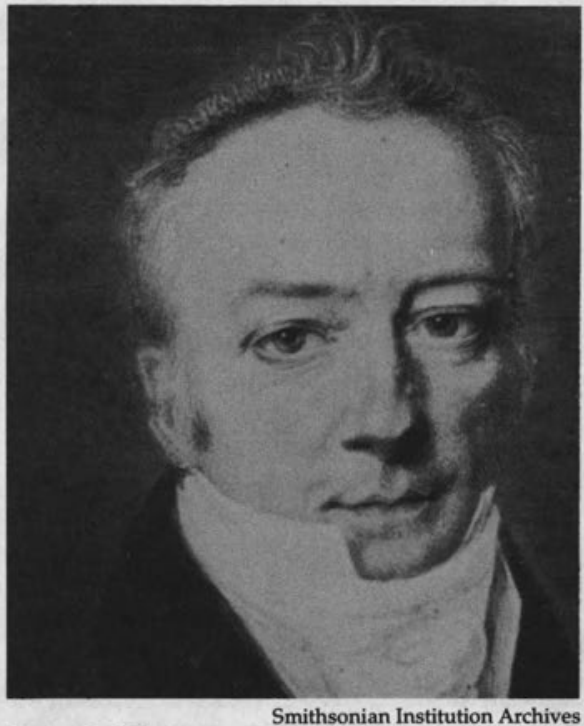

James Smithson

liance to thwart Henry's policies and direct a larger share of resources toward building both the library and a museum, but that eventually Jewett lost out to a Henry-Baird alliance. ${ }^{3}$ Whatever the truth, a short chronology of events of the

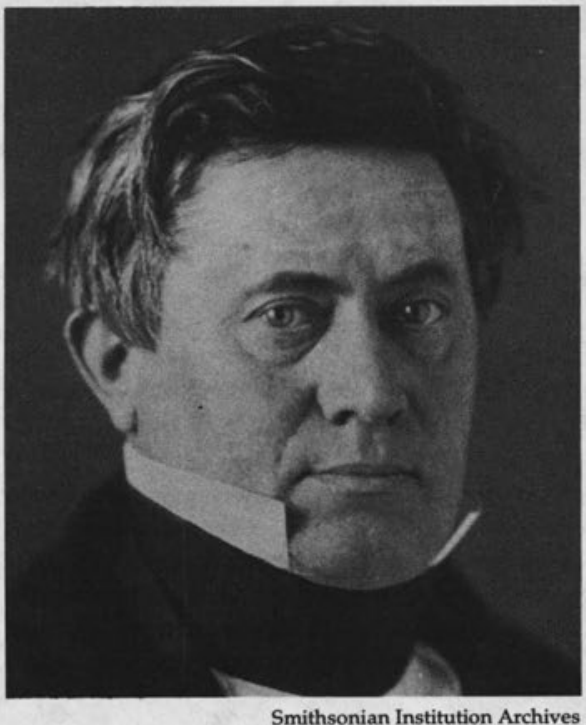

Joseph Henry 


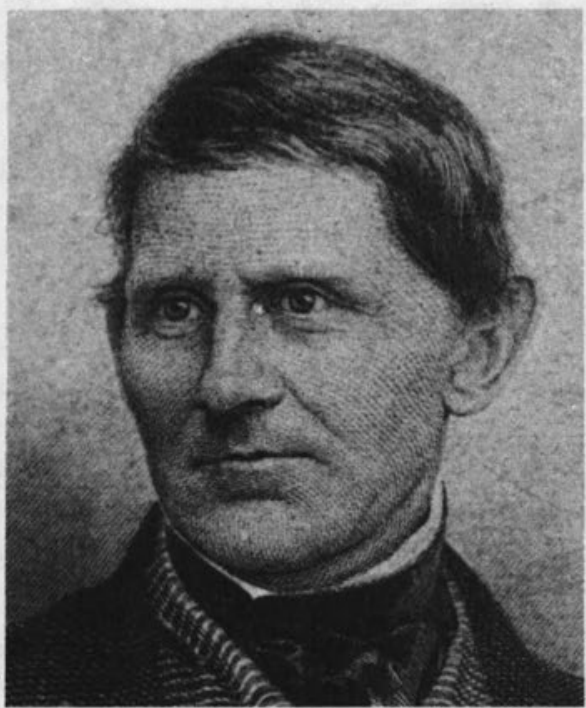

Charles Coffin Jewett

Smithsonian Institution Archives

next 100 years will provide background for a discussion of the nature of library collections management in the Institution today.

- 1854-Joseph Henry fires Charles Coffin Jewett over the strenuous objections of many members of Congress and

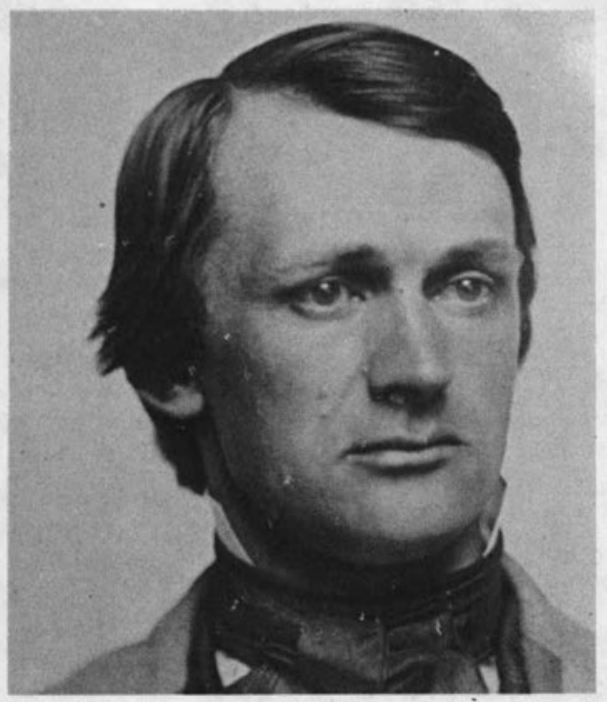

other highly placed political supporters.

- 1857-Henry succeeds in having the Smithsonian removed from the copyright deposit provision.

- 1865-A fire destroys the roof, all the interior of the upper story of the main part of the Smithsonian Castle, and the interior of three towers.

- 1866-By congressional authority, the Smithsonian library $(40,000$ vols.) is removed to the new fireproof extension of the Library of Congress, to be housed separately and to become known as the Smithsonian Deposit. A small reference collection remains behind.

- 1877-Following the Philadelphia Centennial Exposition, the best foreign and state exhibits are donated to the Smithsonian and loaded in sixty-six freight cars for the journey to Washington.

- 1881-Smithsonian Secretary Baird opens the new U.S. National Museum (today's Arts \& Industries Building) and establishes an official "National Museum Library," donating to it his own extensive private library. In the words of one chronicler:

In response to a special circular many of the museums and scientific societies of Europe and America contributed sets of their publications, and new exchanges for the Museum's own publications were arranged. Second copies of many of the more important series received by the Institution for the Smithsonian Deposit were also obtained by exchange, and other material was purchased.

- ca. $1887-$ Since it was apparent by this time that the Library of Congress, "then filled to overflowing, could no longer care for any increase, and could not even render accessible what it already had on its shelves, [it] was accordingly found essential to care for at the Institution those works which were most needed." ${ }^{5}$

- 1912-The bulk of the library is moved from the "old" National Museum to the "new" U.S. National Museum (now Natural History); Smithsonian books are now spread among at least thirty locations, a situation that still pertains today. 
- 1952-Smithsonian Secretary Carmichael concludes an agreement with the Librarian of Congress to transfer the Smithsonian Deposit-by then grown to one million volumes-to the Library of Congress, which absorbs it into the LC stacks to form the nucleus of its great scientific collections. Smithsonian staff are to enjoy the same borrowing privileges as Members of Congress.

- 1963-Book collections left behind in the Arts and Industries Building are moved to the new museum of history and technology (now American History).

- 1968-The National Portrait Gallery and National Collection of Fine Arts (now American Art) move out of the Natural History museum into their own quarters, taking their library books with them. Smithsonian Secretary Ripley approves the establishment of the Smithsonian Institution Libraries under a single, centralized director, to manage the library resources of the Institution. ${ }^{6}$ What this chronology clearly establishes is that researchers need books, they want them close at hand, and as soon as you give a library away, a new one begins to grow in its place. Given this brief history, what does the Institution, and its library system, look like today?

"Many persons who have visited Washington have some sense of the complexity of the Smithsonian, which is described in many colorful ways, including 'the nation's attic,' and 'the octopus on the Mall.' "'

Many persons who have visited Washington have some sense of the complexity of the Smithsonian, which is described in many colorful ways, including "the nation's attic," and "the octopus on the Mall." One observer has described the Institution's organizational development in this way:

One of the results of the Smithsonian's penchant to take on new jobs, to take up new lines of research, or to reactivate old ones has been a breakdown to some degree in its compartments of organization. Some of the new offices created seem to defy the logic of traditional organization and make an organization chart look as if a hurricane had struck it. Organization development is not a straight line but a circle, whereon centralization follows on the heels of decentralization and vice versa.?

The structure of the Smithsonian Institution Libraries mirrors this centralized system of decentralized functions; its collections are organized administratively into fourteen branches, but with at least three times that number of official physical locations where collections are actually housed, including a remote storage site. Figure 1 shows where the SIL branches are distributed, and for the most part their locations are self-evident. Most are on or near the Mall in Washington, but four are outside, in Boston; New York; Edgewater, Md.; and the country of Panama. Without a separate library building (except in Panama, where we have a new, airconditioned, modern facility), SIL exists behind the scenes in nonpublic areas, which accounts for a good part of its invisibility. The collection totals just over one million volumes; the materials budget also hovers at the $\$ 1$ million mark. All

\section{BRANCHES of the SMITHSONIAN INSTITUTION LIBRARIES \\ Central Reference and Loan Services \\ Cooper-Hewitt Museum \\ New York, New York \\ Museum Reference Center \\ Museum Support Center \\ National Air and Space Museum \\ National Museum of African Art \\ National Museum of American History \\ National Museum of Natural History \\ National Zoological Park \\ Office of Horticulture \\ Smithsonian Astrophysical Observatory \\ Cambridge, Massachusetts}

Smithsonian Environmental Research Center Edgewater, Maryland

Smithsonian Tropical Research Institute

Republic of Panama

Special Collections 
branches, no matter where they are located, support all Smithsonian personnel.

These facts-SIL's collective size, its decentralized structure, its location in a congeries of museums and research organizations with overlapping functions-place SIL both with $a$ foot in three camps-sort of balanced precariously on a three-legged stool, if you like-and afoot in three camps-that is, in action, or operation, simultaneously in all three.

And what are the camps, or should we say, environments? Museums, research libraries, and special libraries. The philosophies, principles, ways of thinking, and methodologies of each of these worlds influence the activities and directions of the Smithsonan's libraries at all levels. At different times and in different situations, one or the other may predominate, and occasionally they conflict. But they also lead to SIL's own brand of creativity, in the same way that the Smithsonian's status as part federal, part private works to the Institution's benefit. And it certainly keeps the staff flexible!

The balance of this article explores collection management and preservation issues as they relate to each of these environments. It isn't a particularly neat or well-defined picture.

\section{"A central issue for the Smithsonian, and perhaps for all libraries in muse- ums is simply: are library collections really collections?"}

\section{A QUESTION OF COLLECTIONS}

Let's take the first example. A central issue for the Smithsonian, and perhaps for all libraries in museums is simply: are library collections really collections? That is, collections in the museum sense of the word. It is important to answer that question, for it has crucial fiscal impacts. For example, SIL was not included when the Institution went to Congress in 1978 for special funds to underwrite a massive inventory (known internally as "The Great Count'). To inventory a collection prop- erly, as you know, requires records of what you have, so this funding was important to SIL as a way of supporting backlog cataloging and retrospective conversion.

Secondly, in 1980 the Institution issued a policy mandating that certain Smithsonian bureaus that have collections produce a collections management policy. ${ }^{8}$ The 1987 revision of this document listed fifteen museums and other units to which it applied, including places like the Office of Horticulture and the Smithsonian Furnishing Collections, but nowhere in this list appeared the libraries. Yet most of the functions covered in this document are performed by the libraries, even if the lexicon used to describe them varies somewhat from standard library terminology. We "accession" items (read "catalog"), "deaccession" them (read "withdraw"), and "dispose" of them (read "discard"); we have "incoming" and "outgoing" (read "interlibrary") loans, as well as exhibition loans, the procedures for which exactly match the museum's; we acquire items by gift and purchase, care for, store, and conserve our collections, and fuss about insurance. And we do much of this more frequently than most of the other bureaus.

Yet a third example is embodied in a program called the Collections Acquisitions Program, in which the Institution sets aside from its unrestricted trust funds several million dollars over a five-year period to support the purchase of very costly items or collections and to allow for quick movement when opportunities arise. Again, the list of Smithsonian units eligible for the funds included museums, but not the libraries. Yet if SIL is to add significantly to its rare book holdings or to purchase large collections, access to such funds is essential.

Happily, SIL has had some success in correcting these oversights. Congress eventually supplied the missing inventory funds, and SIL is well on the way to cleaning up its backlogs. The newly hired Smithsonian Registrar has begun a major overhaul of the Institution's collections policies with SIL participation. Finally, a recent revision of the Collections Acquisi- 
tions Program sets aside part of the funds in a pool to which a number of nonmuseum units may apply, including SIL. Functioning in the Smithsonian's museum environment definitely affects SIL's strategy: to compete successfully, the libraries' role as a collector must be taken seriously throughout the Institution.

Yet library collections are not museum collections. With the obvious exception of some of SIL's special collections, they are not composed of individually unique objects. Library administrators in museums must guard against building such strong alliances with museum processes that they lose the flexibility of managing collections like responsible, professional librarians, constantly fine-tuning the holdings to meet the Institution's research and information needs.

\section{IN THE MUSEUM CAMP}

The Smithsonian's library used to assign accession numbers to every incoming item; this procedure was halted long ago. Provenance is critical for museum objects but is unimportant for the bulk of our general collections. Our methods of bibliographic control and data sharing are far ahead of museum processes; but our problems may have been easier to solve. Certainly they pale into insignificance when set beside the need to etch accession numbers into every bone of bird's skeleton, or the fact that there are 300,000 rodents that haven't been cataloged yet (perhaps as many as 1,000 mice in a single case!). A museum cannot count on another museum to catalog an identical specimen, and then borrow and adapt the record. Both need ready access to information about what they have; but only libraries have been able to capitalize on the cost-effective sharing of data, which is largely responsible for the high level of access to collections libraries enjoy. But if we are ahead of museums in terms of access to collections, we have much to learn from them in terms of physical security and documentation, especially as it applies to handling of rare and valuable volumes, interactions with donors, the politics of cultivating gifts, or deaccessioning unwanted items.
To get back to one of the original questions, curatorial or other research staff demands on the libraries are not that much different from what university faculty demand. They want materials when they want them and for however long they want them. They want to download the results of bibliographic online searches and to borrow every item cited. SIL strives hard to supply the resources, just as any academic library does, and struggles in the same way when one user wants the same book that has been loaned to another. A major problem is that we are forced to house large portions of the collections in departmental spaces, which reduces our ability to govern the collections as efficiently as we would like.

For the most part, SIL does not have to cope with a high level of undergraduate student demand. This is not to say that there are no students. The Smithsonian gives out over a million dollars in fellowship and grant funds every year, which support a wide variety of predoctoral students, postdoctoral research fellows, interns, and other transient affiliated staff who use SIL's services. In addition, some museums have combined degree program affiliations, such as the master's degree awarded by the Parson's School of Design with the Cooper-Hewitt Museum, or other arrangements, such as exist between the Tropical Research Institute and the University of Panama, which entail use of library resources by classes of students. By and large, however, SIL is able to control this use and to safeguard its resources when necessary.

\section{AS A RESEARCH LIBRARY}

Bringing up the subject of students moves us from the museum camp to the academic milieu, into the world of research libraries. Here one finds SIL functioning somewhat schizophrenically. On the one hand, looking at the collections as a whole, SIL covers a broad spectrum of disciplines, with wide-ranging historical collections in a number of fields, specifically natural history (with an emphasis on taxonomy and anthropology), history of science and technology (with an emphasis on America), decorative arts and design, 
African art, aeronautics, astrophysics, and conservation science. We are constantly adding older, retrospective works-particularly nineteenth-centuryto the collections, in part still filling in those gaps left by the move of the Smithsonian Deposit 122 years ago, and some branches are taking on archives and other special format materials as well, adding, of course, to their Institutional dispersion. SIL staff constantly identify rare materials in the general collections and transfer them to special collections locations, where there is better environmental control and physical security.

SIL units are connected internally by an online catalog, with terminals in every branch and location, and nationally to OCLC, which displays one holding symbol for the Smithsonian (SMII) (although the books themselves may be anywhere from Boston to Washington to Panama!). Branch staff make selection and deaccession decisions based on what is held across the system, attempting to keep duplication to a minimum. Serials inflation is hurting us badly. We have developed approval plan profiles and are experimenting with a vendor notification program. A self-study team conducted a preservation survey, with a modest preservation microfilming program as one result. In short, SIL is moving in the same direction as most research libraries, and applying similar programs and principles.

\section{". . . the SI Libraries has been under- going binary fission (to borrow a bio- logical term), an amoeba-like split- ting that mirrors the idiosyncratic division of the Smithsonian into its panoply of museums, offices, and bureaus."}

The Smithsonian Libraries shares a continuity of development and age comparable to the major research libraries of the country; yet as the chronology clearly shows, while most of these libraries have been consolidating collections and build- ing large, centralized facilities, the SI Libraries has been undergoing binary fission (to borrow a biological term), an amoeba-like splitting that mirrors the idiosyncratic division of the Smithsonian into its panoply of museums, offices, and bureaus. According to the Concise Columbia Encyclopedia, amoebas "constantly change their body shape as they form temporary extensions, or false feet, used for feeding and locomotion." "Our "extensions"-or branch libraries and sublocations-are certainly not temporary, but they do provide locomotion and may cause SIL's "body shape" to appear to the outside world like a federation of special libraries.

\section{AS A SPECIAL LIBRARY}

So, like a chameleon, the appearance of the libraries changes if viewed from a different angle against a different background. The Museum Reference Center, a branch devoted to providing information about information on museums and museology to an international constituency, and branches in the Office of Horticulture, the Smithsonian Astrophysical Observatory, and the Tropical Research Institute, with their narrowly defined subject collections, clearly function as special libraries. SIL has only recently begun to move away from almost total dependence on curators for selection decisions to assuming responsibility for anticipating future needs and filling in gaps between curatorial specialties. As collections continue to grow, as library management continues to follow the paths laid out, and as the staff assume more and more of a systemwide view, our special library coloration may begin to fade.

\section{BOOK PRESERVATION IN A MUSEUM ENVIRONMENT}

The topic of preservation brings us full circle back into the museum world, but within that context trying to raise awareness and make visible a research library problem. It is not hard to sell the idea of conservation within a museum complex, especially one that considers itself to have national and international missions.

Ten years ago, the libraries experienced no objections to the establishment of a 
Book Conservation Laboratory. After all, there were already eight conservation laboratories in the Smithsonian, in addition to a Conservation Analytical Laboratory. Several of the laboratories are concerned with paper or works of art on paper, but no laboratory was concerned specifically with books. At least part of the stimulus for the establishment of this laboratory lay in the desire to ensure that the SIL materials are exhibited successfully and without serious damage. A substantial portion of the laboratory's work entails preparing books to withstand the rigors of exhibit, taking apart books so that plates can be exhibited individually, checking exhibit installations, monitoring exhibit conditions, and reviewing facilities reports.

At about the same time that the laboratory was established, SIL received from Dr. Bern Dibner its most significant gift of scientific rare books and manuscripts, the nucleus for our Dibner Library of the History of Science and Technology. Today there are at least 30,000 volumes housed in SIL's various special collections facilities, many of which require conservation work.

However, if SIL had not existed in a museum environment, it might not have begun its preservation program with such an emphasis on the artifactual. And a theoretical/administrative acceptance of the need for conservation does not necessarily mean that Smithsonian staff handle books with any greater care, nor are they necessarily more aware of the preservation challenges inherent in a growing number of brittle books.

SIL was already painfully aware of the deterioration of its collections when I arrived in 1984 and used standard techniques for slowly enhancing and redirecting its preservation resources. In 1985, the libraries embarked on a year-long Preservation Planning Program, one of the ten institutions selected to engage in this effort by the Association of Research Libraries. Our results were much in line with those of other libraries, as seen in table 1: brittleness shows up in over 30 percent of our collection, with other kinds of problems less pervasive but often equally serious. ${ }^{10}$ The impact of this information,
TABLE 1 SMITHSONIAN INSTITUTION LIBRARIES
PRESERVATION SURVEY, 1986: MOST SERIOUS PHYSICAL PROBLEMS

\begin{tabular}{lcr}
\hline \hline Problem & \% of Sample* & $\begin{array}{r}\text { Extrapolated to } \\
\text { SIL Collections }\end{array}$ \\
\hline Brittleness & 30.4 & 304,000 \\
Red Rot & 6.6 & 66,000 \\
Detached covers & 2.8 & 28,000 \\
Detached pages & 2.7 & 27,000 \\
Pages stuck & 2.6 & 26,000 \\
$\quad$ together & & \\
Missing spines & .9 & 9,000 \\
Missing covers & .6 & 6,000 \\
Mold/mildew & .2 & 2,000 \\
\hline
\end{tabular}

•Sample $=1,088$ volumes.

combined with the momentum of the planning process, has allowed us to move in several ways to increase the preservation attention given to our general collections. But to make a significant impact will require increased funding.

It is not surprising that a large proportion of SIL volumes are heavily illustrated, given the major emphasis of Smithsonian research on systematics and taxonomy, which requires reference to illustrations of species; materials culture, which requires identification and provenance of objects; and fine arts. One of the libraries' most important collections is its commercial catalogs, which currently number upwards of 150,000 pieces and which are being aggressively developed. The 1925 " back-toschool" publication from Marshall Field, the advertisements at the beginning and end of yellowing railroad timetables, wallpaper and textile sample books, plans for the layout of the midway at numerous world's fairs: all are primary grist for the Smithsonian's research mill and present preservation challenges. For in selecting appropriate methods of preservation, SIL must be constantly aware of the exhibition potential of even the most ordinary book or journal.

Currently SIL has boxed and stored, for example, a year's worth of issues of the tabloid-sized Computerworld. Why? Because we routinely discard it in favor of microfilm; because many, many libraries do the same thing; and because the $\mathrm{Na}$ tional Museum of American History has 
asked us to do so in case the issues are needed for the museum's forthcoming exhibit entitled the Information Revolution. This kind of consideration mandates a more conservative approach to our preservation decisions than may be necessary or desirable elsewhere. And we must again retain our perspective within the Institution. SIL can count on other libraries' preserving many items that it will need; SIL can probably count on sympathy for its preservation needs and on a certain level of support. But the Smithsonian must also worry about the stretching fabric in the inaugural ball gowns of the First Ladies, on replacing the formaldehyde in jars on miles of shelves, on finding those 1,000 mice in the drawer when it becomes possible to catalog them, and on housing the Space Shuttle. We will need to be creative to compete successfully for major book preservation support in the context of the large-scale needs of the entire Institution.

I would like to close on a realistic note about our role, and the role of most libraries, whether within universities, museums, companies or other organizations. Certainly in any knowledge-producing, educational environment, libraries are often referred to as the heart of the organization. A much more apt metaphor can be found in Robertson Davies' novel Fifth
Business. In speaking to the protagonist, Dunstan Ramsey, a female character named Leisl says:

"Who are you? Where do you fit into poetry and myth? Do you know who I think you are, Ramsey? I think you are Fifth Business.

You don't know what that is? Well, in opera in a permanent company of the kind we keep up in Europe you must have a prima donnaalways a soprano, always the heroine, often a fool; and a tenor who always plays the lover to her; and then you must have a contralto, who is a rival to the soprano, or a sorceress or something; and a basso, who is the villain or the rival or whatever threatens the tenor.

So far so good. But you cannot make a plot work without another man, and he is usually a baritone, and he is called in the profession Fifth Business, because he is the odd man out, the person who has no opposite of the other sex. And you must have Fifth Business, because he is the one who knows the secret of the hero's birth, or comes to the assistance of the heroine when she thinks all is lost, or keeps the hermitess in her cell, or may even be the cause of somebody's death if that is part of the plot. The prima donna and the tenor, the contralto and the basso, get all the best music and do all the spectacular things, but you cannot manage the plot without Fifth Business! It is not spectacular, but it is a good line of work, I can tell you, and those who play it sometimes have a career that outlasts the golden voices. Are you Fifth Business? You had better find out."11

\section{REFERENCES AND NOTES}

1. Paul H. Oehser, The Smithsonian Institution. 2d ed. (Boulder, Colo.: Westview Press, 1983), p.5.

2. Ibid., p.10.

3. Joel J. Orosz, "Disloyalty, Dismissal, and a Deal: The Development of the National Museum at the Smithsonian Institution, 1846-1855," Museum Studies Journal 2:22-33 (Spring 1986).

4. Leila F. Clark, "The Library of the Smithsonian Institution," Science 104:143-44 (Aug. 9, 1946).

5. Report of the Librarian of Congress for the Fiscal Year ended June 30, 1898. Senate Document 24, 55th Congress, 3d Session (Washington, D.C.: Govt. Print. Off., 1898), p.71.

6. SIL's management of all library resources has never been fully implemented. The libraries of four Smithsonian art museums remain outside of the system.

7. Oehser, Smithsonian, p.187.

8. The Smithsonian uses the term "bureau" to denote major organizational divisions such as museums, research institutes, and major support units.

9. The Concise Columbia Encyclopedia (New York: Avon, 1983), p.27.

10. Final Report of the Preservation Planning Program. (Washington, D.C.: Smithsonian Institution Libraries, 1986), p.2.

11. Robertson Davies, Fifth Business (New York: Penguin, 1977 [cl970]), p.227. 